College of William \& Mary Law School William \& Mary Law School Scholarship Repository

1986

\title{
On the Limits of Court-ordered Social Change: A Critical Look at Dimond's Beyond Busing
}

Neal Devins

William\& Mary Law School, nedevi@wm.edu

\section{Repository Citation}

Devins, Neal, "On the Limits of Court-ordered Social Change: A Critical Look at Dimond's Beyond Busing" (1986). Faculty Publications. 404.

https://scholarship.law.wm.edu/facpubs/404

Copyright c 1986 by the authors. This article is brought to you by the William \& Mary Law School Scholarship Repository. 
Review Essay

\title{
On the Limits of Court-ordered Social Change: A Critical Look at Dimond's Beyond Busing
}

Neal E. Devins

\author{
Paul R. Dimond, Beyond Busing: Inside the Challenge to Urban Segrega- \\ tion. Ann Arbor: University of Michigan Press, 1985. Pp. xii +411. \\ $\$ 29.95$.
}

One central inquiry underlies all race discrimination cases-namely, what would the world look like in the absence of illegal discrimination? If the world were naturally integrated, statistical imbalance would serve as proof of discrimination. Moreover, in such a world, expansive race-conscious remedies should be used to ensure "natural" racial balance. If the world, absent illegal discrimination, were racially imbalanced, however, reliance on such statistical measures would be inappropriate. In such a world, proof of discrimination must hinge on evidence that suggests the existence of some discriminatory animus. Correlative to this, judicial remedies in a racially imbalanced world should seek only to redress the consequences of proven discrimination.

In school desegregation cases, the Supreme Court-by using contradictory evidentiary presumptions and principles of law-has vacillated between the two models. ${ }^{1}$ Social scientists too have reached conflicting conclusions on this matter. ${ }^{2}$ Finally, the Nixon, Ford, Carter, and Reagan

Neal E. Devins is assistant general counsel at the U.S. Commission on Civil Rights; beginning in summer 1987, he will be assistant professor of law, Marshall-Wythe School of Law, College of William and Mary. B.A. 1978, Georgetown University; J.D. 1982, Vanderbilt Law School. The views expressed are those of the author.

1. Supporting the naturally integrated model are Court holdings which suggest that black-white student population ratios measure the adequacy of a school desegregation plan, Green v. County School Bd., 391 U.S. 430 (1968), and Court decisions which have found that intentional discrimination in one portion of a school district creates a presumption that there may be purposeful discrimination in other portions of the school district, Keys v. School Dist. No. 1, 413 U.S. 189 (1973). Supporting the possibly segregated model are Court holdings that demand proof of intentional discrimination even if racial imbalance is the natural and foreseeable consequence of school board action, Austin Indep. School Dist. v. U.S., 419 (1976) (mem.), and Court rulings that limit desegregation remedies to the demonstrable incremental effect of specified discriminatory conduct, Dayton Bd. of Educ. v. Brinkman (Dayton I), 433 U.S. 406 (1977).

2. With respect to housing, some social scientists argue that "socioeconomic differentials do not account for residential segregation; discrimination by agents in the housing market . . as well as government regulations ... are likely contributors." Streitweisser \& Goodman, A Survey of Recent Research on Race and Residential Location, 2 Population Research \& Pol'y Rev, 253, 265 (1983). Other 
administrations have each approached this issue differently. ${ }^{3}$ Sharp contrasts within judicial reasoning, social science research, and partisan politics make unlikely the attainment of consensus on the vexing and fundamental problem of which of the two models should shape decision making in this area. Yet, like other divisive matters, the desegregation issue gives rise to important books that advocate one of these world visions.

Paul Dimond's Beyond Busing, ${ }^{4}$ a fascinating first-hand account of 1970 s northern school desegregation decisions, provides another worthwhile per-

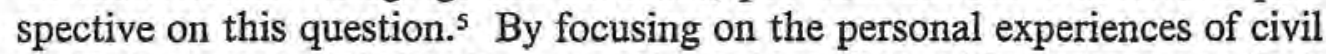
rights lawyers and their witnesses, Dimond provides a "human perspective" to support his conclusion that blacks are victimized by pervasive "caste" discrimination. For Dimond, caste discrimination involves the containment of the minority community by the dominant white culture through various economic and social customs. To eradicate such discrimination, Dimond argues, judicial remedies must right the social condition thrust upon minority America. Specifically, Dimond asserts that courts should not limit their focus to the incremental effects of specific discriminatory acts. Instead, courts must recognize that racial isolation is the by-product of numerous contributing factors, ranging from social customs to intentional discrimination.

This argument certainly is provocative, but it is not persuasive. In my view, Dimond's understanding of the causes of racial imbalance and the scope of judicial authority is too simplistic. Furthermore, his notion of pervasive caste discrimination is greatly exaggerated. The world cannot be viewed in such absolutist terms. I do not doubt that discrimination has impeded the progess of black people. But Dimond goes too far in using the collective sins of a dominant white culture as an escape hatch for the problems of blacks. Numerous factors-including but not limited to discrimination-explain racial separation.

\footnotetext{
social scientists, however, conclude that the migration of whites from city to suburb is not a result of racial concerns but of lower tax rates, lower per capita school expenditures, and expanded employment opportunities. See id. at 262. See also Hearings on School Desegregation Before the Subcomm. on Civil and Constitutional Rights of the House Comm. on the Judiciary, 97th Cong., 1st Sess. 160 (1981)(testimony of Gary Orfield). Another pertinent issue on which social scientists differ is the degree of white resistance to expansive school desegregation orders. Suggesting that the world is naturally integrated, some social science research indicates that comprehensive metropolitanwide desegregation remedies ultimately lead to decreases in white fight/residential segregation. See $i d$. at 161 (statement of Gary Orfield). In contrast, suggesting that the world is possibly segregated, some social science research attributes white flight and social segregation to mandatory pupil transportation remedies. See id at 205-12 (statement of David Armor).

3. See generally Devins \& Stedman, New Federalism in Education: The Meaning of the Chicago School Desegregation Cases, 59 Notre Dame L. Rev. 1243 (1984).

4. Although principally concerned with school desegregation litigation, Dimond devotes some attention to housing segregation cases (at 183-225). Since Dimond interweaves the issue of housing discrimination with his discussion of school desegregation, this essay will view the housing question as a subset of school desegregation.
}

5. See also D. Kirp. Just Schools (1982); J. Wilkinson, From Brown to Bakke (1979). 
Dimond's recommendations regarding appropriate judicial action are also troublesome. Although I concur with many of his criticisms of Supreme Court school desegregation cases, I do not think that the Court should abandon traditional judicial restraint in order to become a social crusader. Unlike legislative hearings designed to ascertain the underlying causes of a range of social problems, the judicial inquiry is more narrowly defined. School desegregation cases, therefore, do not provide the appropriate forum to explore personal prejudice and social customs. In fact, unless prohibited by the Constitution or statutory law, certain forms of discriminatory conduct are not subject to judicial review. Furthermore, since Dimond's model would permit a black plaintiff to extend a discrimination lawsuit beyond traditional notions of injury to the pervasive web of discrimination that characterizes urban America, courts would be forced to abandon such article III justiciability requirements as injury in fact and redressability. Aside from being mandated by our system of separation of powers, these justiciability requirements make practical sense. Courts may not have the institutional capability to implement far-reaching social reform.

Dimond, finally, fails to consider the fundamental importance of the private marketplace and individual choice. In his eagerness to argue that caste discrimination is a meritorious egalitarian concept, he ignores other values fundamental to American policy that might counter his views.

\section{Dimond's Assessment of Race Relations and the Courts}

Beyond Busing is not concerned with the success or failure of pupil transportation remedies. Instead, by looking at the human side of 1970 s school desegregation cases, Dimond seeks to understand whether America is still divided by a color line. He focuses on the school desegregation cases because "a primary goal of [these] cases of the 1970s has been to raise the issue whether a form of apartheid splits much of metropolitan America on a racial basis" (at vi). The cases that Dimond refers to are Milliken v. Bradley in Detroit, ${ }^{6}$ Dayton v. Brinkman, ${ }^{7}$ Columbus School Board v. Penick, ${ }^{8}$ and Evans v. Buchanan in Delaware.

In these cases, Dimond feels that civil rights attorneys (such as himself) ${ }^{10}$ endeavored to have courts come to terms with the underlying causes of societal discrimination. During the course of these trials, personal accounts of segregative treatment were presented by prominent members of the black community (at 50-54); maps were drawn demonstrating that discriminatory housing practices forced blacks into the inner city (at 39-40); black

6. 418 U.S. 717 (1974); discussed in Dimond, at 21-118.

7. Dayton I, 433 U.S. at 406 (1977); Dayton Bd. of Educ. v. Brinkman (Dayton II), 443 U.S. 526 (1977). These cases are discussed in Dimond at 121-80, 343-94.

8. 443 U.S. 449 (1979); discussed in Dimond at 229-79, 343-94.

9. 447 F. Supp. 982 (D. Del. 1978), aff'd 582 F.2d 750 (3d Cir. 1978)(en banc), cert. denied, 46 U.S. 923 (1980); discussed in Dimond at 283-339.

10. Dimond served as co-counsel to plaintiffs in these school desegregation cases. 
teachers and school administrators recounted efforts by their school districts (or city governments) to keep white and black students separate and to deny resources to black students that were provided to whites (at 3-17); and sociologists and educators-serving as expert witnesses-argued that discrimination was the most likely explanation for government conduct that perpetuated racial isolation (at 37-38).

Through the introduction of such evidence, civil rights attorneys sought to accomplish two related tasks. First, by showing that the school district had been actively involved in creating and maintaining a dual school system, these attorneys wished to show that a systemwide desegregation plan with mandatory components was needed to ensure equal education opportunity to black school children. Second, by introducing evidence of pervasive "caste" discrimination, these attorneys hoped that school desegregation cases would extend to housing and other discriminatory practices within the district and would extend beyond the school district to the entire metropolitan community. Dimond argues that this bifurcated approach was a practical necessity:

For a plain justice of the peace concerned about basic fairness, it might be enough to argue that school authorities may not incorporate the larger community's discriminatory system of racial containment into the schools. But we intended to show more, that school authorities also manipulated their neighborhood zoning policy to fuel the system of racial ghettoization. That was the only way to secure our position [in the courts]. (At 56)

From plaintiffs' perspective, the results of this approach were mixed. Attorneys were unable to broaden the judicial inquiry beyond school district conduct and school district boundaries. Systemwide relief, however, was ultimately ordered in Dayton, Columbus, and Detroit, and interdistrict relief was mandated in Delaware.

Dimond's perceptions are best expressed in his analysis of the Detroit case, Milliken v. Bradley. In Milliken, the plaintiffs' attorneys convinced District Court Judge Stephen Roth both that school desegregation was an attribute of pervasive community discrimination and that-due to the containment of blacks in the inner city-an effective school desegregation remedy must extend beyond school district boundaries to the entire metropolitan area." Making these findings, Judge Roth ordered Detroit and its suburbs to formulate a mammoth interdistrict desegregation plan.

11. The district court found: "Residential segregation within the city and throughout the larger metropolitan area is substantial, pervasive and of long-standing. . . . While the racially unrestricted choice of black persons and economic factors may have played some part in the development of this pattern of residential segregation, it is, in the main, the result of past and present practices and customs of racial discrimination, both public and private, which have and do restrict the housing [and educational] opportunities of black people" (quoted at 399). 
This decision, in Dimond's view, exemplifies the ability of an openminded judiciary to address pervasive "caste" discrimination. According to Dimond:

Judge Roth came to know the color line of racial ghettoization in his own state: he found that an interlocking web of public, community, and private discrimination contributed to the containment of black families and children in segregated housing and schools separate from whites-only housing and schools. He ... determined that school segregation must be declared unconstitutional so that all people would finally come to grips with the continuing color line in American life. (At 73)

Dimond finds this determination especially significant since, at the start of the case, Judge Roth was unsympathetic toward minority claims. In other words, Dimond feels that this "dramatic conversion" in Judge Roth demonstrates the strength of civil rights attorneys' proof of pervasive "caste" discrimination.

The Supreme Court, however, rejected this comprehensive approach and held that without proof of intentional discrimination in Detroit's surrounding suburbs, school desegregation remedies are limited to a school system's geographic boundaries. In so ruling, the Court insisted on such "legal formalisms" as the rules that only perpetuators of intentional discrimination are subject to desegregation obligations and that the scope of the violation defines the scope of the remedy.

Criticizing this decision, Dimond claims that "the Court's view of the nature of the violation did not even begin to address the state's responsibility for the wrong of containment, the color line of racial ghettoization and whites-only protection in metropolitan Detroit" (at 112-13). Especially irritating to Dimond was the Court's failure to consider evidence of metropolitanwide housing discrimination; ${ }^{12}$ evidence that might have established a nexus between overwhelmingly black inner-city public schools and overwhelmingly white suburban schools. ${ }^{13}$

Dimond argues that the Court must address the basic question of whether "racial separation in America [is] a legacy and an engine of caste discrimination, or ... a matter of voluntary choice and ethnic diversity" (at 399). Dimond thus is highly critical of Supreme Court decisions, like Milliken, where fundamental questions regarding the underlying causes of segregation are eschewed by the Court. ${ }^{14}$ To him, by not addressing these

12. The Court claimed that it could not resolve this issue since it had not been considered by the appellate court. But, as Jay Wilkinson recognized: "In failing to remand to [the] district court for findings on past housing practices or even to explain their relevance, the Supreme Court failed to address the foremost cause of metropolitan segregation." J. Wilkinson, From Brown to Bakkie 223-24 (1979).

13. Several instances were cited where discriminatory housing practices combined with a neighborhood school policy "'naturally, probably, and foreseeably" resulted in segregation in the face of available desegregation alternatives" (at 62).

14. Dimond's depiction of other cases likewise reflects his perception that courts should undertake a comprehensive analysis of the condition of racial separation. In the Daytont case, Dimond lambastes District Judge Carl Rubin for failing to consider evidence of discrimination in public housing. Alterna- 
fundamental questions, the "justices sought to absolve white America from responsibility for the ghetto" (at 396). Criticizing the Supreme Court's use of "legal formalisms" to frame school desegregation and other civil rights cases, he argues:

We are not well served by a Court that whitewashes claims of violation, argues that the judiciary ought not hear claims of general social injustice unless specific judicially manageable remedies running against particular wrongdoers are apparent, is so concerned about the extent of effective remedies that rationalizations of wrong as innocent conditions overwhelm, or order sweeping remedies on the narrowest judicial prescription that particular wrongs require specific remedies. (At 400)

In pleading that the Court rethink its compartmentalized approaches to segregation, Dimond would have the judiciary serve a quasi-legislative factfinding role. Each instance of discrimination would be the tip of an iceberg of purposeful caste discrimination. Under this approach, school desegregation cases would become general desegregation cases, involving the judiciary in related inquiries of discrimination in housing, employment, etc. Furthermore, in Dimond's model, judicial remedies would extend beyond school districts to municipalities and beyond education policy to housing and employment. In other words, the courts would take on a quasi-executive role in ensuring that government practices do not perpetuate caste discrimination.

\section{Analysis of Dimond's Theory}

Beyond Busing strongly supports the view that housing and school segregation may be part of an "interlocking web" of discriminatory conduct. On this count, I do not take issue with Dimond; in fact, when limited to this question, few individuals would argue with him..$^{15}$

Dimond, however, goes well beyond this proposition, arguing that all racial imbalance is a by-product of pervasive caste discrimination. In my view, this suggestion is fundamentally flawed. Contrary to Dimond's perception of America's "contemporary, albeit substantially sanitized, form of

tively, District Judge Robert Duncan's Columbus ruling is applauded for its recognition that the "interaction of housing and the schools operates to promote segregation in each" (at 251). Finally, in the Delaware case, Dimond refers to the interdistrict remedy as "complete, effective, and equitable relief from the continuing color line in schooling" (at 334).

15. That school and housing discrimination may feed into each other is undeniable; neighborhood schools often reflect the racial composition of the surrounding residential area. Furthermore, although few court cases have explored the relationship of racial discrimination in education and housing, there are numerous decisions concerning discrimination in either housing or education. With respect to housing, before the mid-1960s, government condoned (and even encouraged) purposeful racial segregation in publicly assisted housing. See A. Hirsch, The Causes of Residential Segregation: A Historical Perspective (paper prepared for U.S. Commission on Civil Rights consultation/hearing on fair housing, Oct. 24, 1985). Since the enactment of fair housing legislation in 1968, numerous municipalities have been subjected to court orders for purposeful discrimination against minorities. 42 U.S.C. $\$ \$ 3601-19$ (1982). See, e.g., United States v. City of Parma, 661 F.2d 562 (6th Cir. 1981). With respect to state-sponsored school segregation, numerous school systems throughout the nation have been found guilty of violating Brown v. Board of Education. See generally Wilkinson, supra note 5. 
apartheid" (at 400), racial segregation is caused by a number of factors. Furthermore, in suggesting that the federal judiciary confront pervasive caste discrimination, Dimond does not heed express constitutional limits on the remedial authority of article III courts, nor does he consider practical limits on such court authority. Finally, Dimond fails to take into account such fundamental American values as individual choice and the free marketplace.

\section{A. Causes of Segregation}

It is naive to suggest that caste discrimination is the sole cause of racial segregation. Voluntary and involuntary forces contribute to such separation. Recent housing studies suggest that "there is no reason to believe that the level of residential segregation observed between [blacks and whites] purely and simply reflects the totality of only one group's demands."16 For example, "middle- and upper-income blacks experience relatively little price discrimination in more affluent white areas."17 Moreover, although whites will pay more than blacks to live in a predominantly white neighborhood, ${ }^{18}$ data suggest that most blacks and whites are willing to live in nonexclusive neighborhoods. ${ }^{19}$

Undoubtedly, the above findings are subject to question and criticism. But even Farley and other researchers who recognized that at one time, "a pervasive 'web of discrimination' prevent[ed] blacks from freely competing for housing," argue:

The continued operation of a web of discrimination is based upon the supposition that there is a strong demand on the part of almost all whites for racially segregated neighborhoods. However, ... [w]hite attitudes have become progressively more liberal with regard to housing opportunities for blacks. Not only do whites endorse the ideal of residential integration, they have become much more willing to live in integrated neighborhoods themselves. ${ }^{20}$

Furthermore, on several occasions, urban white America has sought a constructive voluntary solution to racial separation. For example, in his study of race relations in the San Francisco metropolitan area, Kirp notes efforts by many predominantly white communities to address perceived black needs. ${ }^{21}$ This study, by highlighting the differences between communities in their efforts to eradicate racial injustice, indicates that it is inappropriate to

16. Lieberson \& Carter, A Model for Inferring the Voluntary and Involuntary Causes of Residential Segregation, 19 Demography 511, 524 (1982).

17. Mieszkowski \& Syron, Economics Explanations for Housing Segregation, New Eng. Econ. Rev*, March-April, 1978, at 33, 39. Other researchers, however, have found evidence of discrimination against blacks in housing price differentials and housing search costs. See, e.g., R. Lake, The New Suburbanites: Race and Housing in the Suburbs 172-73, 201-3 (1981).

18. Mieszkowski \& Syron, supra note 17, at 35.

19. Farley, Bianchi, \& Colastano, Barriers to the Racial Integration of Neighborhoods: The Detroit Case, 441 Annals 97 (1979).

20. Id. at 101.

21. Kirp, supra note 5. Kirp's study, however, also notes the hesitancy of some white communities to constructively address race relations. 
make generalizations about white attitudes toward racial isolation. ${ }^{22}$ This perception strongly conflicts with Dimond's vision of judicially and politically condoned "apartheid" in urban America.

The variance between Dimond's theory and much of the existing research is further revealed in studies of residential segregation in Detroit. In Trial and Error, her study of the Detroit case, Wolf concludes: "the trial process, to some extent through distortions, but mainly through omissions in the testimony, produced a picture of residential segregation that was gravely defective." 23 In Wolf's view, rather than relying on norms of scientific inquiry and reporting, civil rights attorneys-by focusing on earlier governmental complicity in housing discrimination and thus "arous[ing] the judge's sense of injustice" 24 _based their cases on proof that was emotional in nature. Also contradicting Dimond's analysis is Farley's 1979 study, which concluded that numerous factors contributed to residential segregation in Detroit. ${ }^{2 s}$

\section{B. The Court's Role}

Dimond's perception that an interlocking system of private and public discrimination contains the black community and limits its opportunities is not readily transferrable into Anglo-American jurisprudence. Article III mandates that courts resolve discrete "cases or controversies." Under this system, a litigant must "show that he personally has suffered some actual or threatened injury as a result of the putatively illegal conduct of the defendant."26 Consequently, a black plaintiff-by virtue of being black-cannot challenge purported discrimination by various governmental and private entities. Dimond's recommendation that the judicial inquiry in discrimination cases be expansive and thorough gives short shrift to this constitutional demand. Under Dimond's model, all blacks would have ready access to the courts, for all blacks suffer injury from an interlocking web of discrimination that comes from the dominant white culture.

Dimond's model, furthermore, fails to recognize that certain types of discriminatory conduct are beyond the purview of the courts. The Equal Protection Clause, for example, does not extend to private entities. ${ }^{27}$ Of equal significance, our constitutional system, for the most part, grants each individual the rights to choose whom to interact with: the First Amendment accords constitutional protection to groups-such as the $\mathrm{Ku} \mathrm{Klux} \mathrm{Klan}$ and Nazis - who engage in racially motivated conduct; parents are free to

22. See Devins, Integration and Local Politics, 73 Pub. Interest 175 (1983).

23. E. Wolf, Trial and Erro 26 (1981).

24. Id. at 81 .

25. Farley, Bianchi, \& Colastano, supra note 19.

26. Gladstone Realtors v. Village of Bellwood, 441 U.S. 91,99 (1979).

27. See, e.g., Moose Lodge No. 107 v. Irvis, 407 U.S. 163 (1972). 
send their children to racially isolated private schools; ${ }^{28}$ families are free to move from racially mixed neighborhoods to racially isolated ones.

Federal courts may also lack the institutional capacity to uphold Dimond's anticaste principle. Courts often cannot fully implement expansive institutional reform decisions. ${ }^{29}$ And without the support of those affected by their rulings, some court holdings are honored more in the breach than in the observance..$^{30}$

By looking at community responses to court-ordered busing, one can see that public consensus is needed for the successful implementation of court decisions. ${ }^{31}$ Charlotte-Mecklenburg, for example, has been quite successful implementing a mandatory busing plan because of support from pupils, parents, and city leaders. ${ }^{32}$

At the other extreme, public opposition to busing has left Boston's public schools more segregated today than they were 14 years ago. ${ }^{33}$ As Alexander Bickel noted: "no policy that a court can order, and a school board, a city or even the State has the capacity to put into effect, will in fact result in the foreseeable future in racially balanced public schools. Only a reordering of the environment ... might have an appreciable impact."34 By recommending an ever-increasing judicial role to address pervasive caste discrimination, Dimond appears unconcerned with Bickel's words regarding public consensus.

The above considerations do not eliminate the possibility of social reform through the law. Discrimination in employment, in land use, and in education can be-and have been-limited through judicial action. Federal courts, however, lack the authority and ability to unilaterally reshape society.

\section{Fundamental Values}

Dimond views statistical disparities between blacks and whites as anathema, necessitating expansive judicial remedies to root out presumptive caste

28. Runyon v. McCrary, 427 U.S. 160 (1976) (recognizing right of parents to send their children to discriminatory private schools).

29. See, e.g., D. Horowitz, The Courts and Social Policy (1977). Compare M. Rebel \& A. Block, Educational Policymaking and the Courts: An Empirical Study of Judicial Activism (1982).

30. See, e.g., W. Muir, Prayer in Schools (1967) (assessing compliance problems with school prayer decisions).

31. Despite Brown and a plethora of lawsuits filed in the wake of Brown, equal education opportunity advanced slowly from 1954 to 1964 . With the passage of the 1964 Civil Rights Act and the Elementary and Secondary Education Act of 1965, great strides were made in the desegregation of southern systems. See Devins \& Stedman, supra note 3, at 1245-58. This change came because these enactments authorized the executive to cut off newly expanded federal financial assistance to discriminatory school systems. Yet, once public opinion toward increasingly expansive desegregation decisions shifted, Congress repealed specific desegregation-related programs, thereby hampering efforts to attain equal education opportunity. See id. Moreover, the Reagan Justice Department is unwilling to pursue mandatory busing remedies. See Speech by William Bradford Reynolds Before the Delaware Bar Association, Feb. 1982 , at 9.

32. See Daniels, In Defense of Busing, N.Y. Times, Apr. 17, 1983 (Magazine), at 34.

33. See Higgins, Boston's Busing Disaster, New Republic, Feb. 28, 1983, at 16.

34. A. Bickel, The Supreme Court and the Idea of Progress 132 (1970). 
discrimination. Basing his theory exclusively on this brand of result-oriented egalitarianism, Dimond apparently feels that values of pluralism and the economic marketplace should not be accorded any weight in a country that unjustifiably contains its urban black population. Dimond, moreover, seems uninterested in rights-oriented liberalism that "seeks a neutral legal framework which assures each individual an equal opportunity to pursue interests and goals as free moral agents." 35 Instead, Dimond seems obsessed with creating a judicial mechanism that will oversee all public and private conduct which affects blacks.

This approach does not consider the rights of the individual. Although the Constitution's equal protection guarantee and antidiscrimination laws are sensible tools for stopping pernicious racial discrimination, individual accomplishments and individual rights must be acknowledged and protected. By equating statistical disparities with illegal discrimination, Dimond improperly ignores the role that the individual does and should play in our culture.

\section{Conclusion}

Beyond Busing aspires to make its readers "[confront] the issue raised by the segregation cases" (at vi). This purpose is accomplished, but with mixed results. Dimond's "human perspective" effectively demonstrates that school desegregation is but one element of the much more pervasive problem of racial separation. In this sense, Dimond places the school desegregation issue into a broader context (hence, the title Beyond Busing). Dimond's notion of caste discrimination is not credible, however. Many factors in addition to discrimination contribute to racial separation. Because he does not consider what role individual choice and personal wealth play in creating racial separation, Dimond's work appears simplistic. His criticisms of judicial decision making are similarly flawed. Constitutional and practical considerations foreclose both judicial findings of caste discrimination and judicial remedies for such violations.

Finally, I question the values that underlie Dimond's model. Egalitarian considerations support antidiscrimination laws and judicial relief for public and private conduct that unnecessarily displaces black interests. But American policy is based both on egalitarian and pluralistic principles; ${ }^{36}$ neither of these competing values should displace the other.

These weaknesses do not undercut the significance of Beyond Busing. Dimond forthrightly admits that his "book may offer a limited perspective because it portrays the apparent certitude of one side in the midst of a complex, adversary struggle" (at 395). And when viewed as the work of an advocate, concerns regarding the accuracy of Dimond's theory of caste dis-

35. Linder, Freedom of Association After Roberts v. United States Jaycees, 82 Mich. L. Rev. 1878, 1881 (1984).

36. See Devins, The Trouble with Jaycees, 32 Cath. U.L. Rev. 901 (1985). 
crimination or his assessment of judicial decision making seem less significant; the reader, instead, may view Dimond's work as the first-hand account of a social crusader. On this level, Dimond succeeds. His insights into the strategies and perspectives of civil rights attorneys are enlightening, as are his perceptions of adversary counsel and trial judges involved in 1970 s segregation cases. Also, although Dimond's fervent advocacy permeates his description of trial court proceedings and his analysis of court rulings, he is quite evenhanded in his explication of these substantive holdings. In short, although I found his conclusions of questionable merit, Professor Dimond's Beyond Busing is a valuable addition to the literature on this most important subject. 